\title{
Synthesis and Characterization of Process-Related Impurities of Antihypertensive Drug Olmesartan Medoxomil
}

\author{
G. Venkanna, ${ }^{1,2}$ G. Madhusudhan, ${ }^{1}$ K. Mukkanti, ${ }^{2}$ A. Sankar, ${ }^{1}$ \\ Y. Sampath Kumar, ${ }^{1}$ and G. Venakata Narayana ${ }^{1}$ \\ ${ }^{1}$ Department of Research and Development, Inogent Laboratories Private Limited, 28A, IDA, Nacharam, Hyderabad 500 076, India \\ ${ }^{2}$ Centre for Pharmaceutical Sciences, Institute of Science and Technology, Jawaharlal Nehru Technological University, Kukatpally, \\ Hyderabad 500 072, India
}

Correspondence should be addressed to G. Madhusudhan; madhusudhan.gutta@inogent.com

Received 18 February 2012; Accepted 17 May 2012

Academic Editor: Andreas G. Tzakos

Copyright (c) 2013 G. Venkanna et al. This is an open access article distributed under the Creative Commons Attribution License, which permits unrestricted use, distribution, and reproduction in any medium, provided the original work is properly cited.

\begin{abstract}
Olmesartan medoxomil (1) is the latest angiotensin receptor antagonist approved by the FDA for the treatment of hypertension. During the process development of olmesartan medoxomil, three process-related impurities were observed along with the final API. These impurities were identified as isopropyl olmesartan (12), dimedoxomil olmesartan (19), dibiphenyl olmesartan (17). The present work describes the synthesis and characterization of all these three impurities.
\end{abstract}

\section{Introduction}

Drugs have become an important part of human life to combat various deceases. Unlike ancient days, most of the drugs in recent years are purely synthetically made. Unambiguously, the synthetic drugs certainly contain various impurities such as either chemical or microbial. But of course most of the impurities are chemical only.

The process-related impurities in an active pharmaceutical ingredient (API) can have a significant impact on the quality and safety of the drug products. The impurity levels in any drug substance are described as per its biological or toxicological data. It is quite important for "regulatory" aspect of drug approval also to provide limitation of "related impurities." Therefore, it is necessary to study the impurity profile of any API and control it during the manufacturing of a drug product. As per the ICH guidelines, any impurities which are forming at a level of $\geq 0.10 \%$ with respect to the API should be identified, synthesized, and characterized thoroughly [1].

Among the various health problems, high blood pressure is one of the critical one, and of course most of the times itself does not harm much, but it leads to various chronic and panic health disorders such as cardiodeceases, cerebral hemorrhage, and others. Olmesartan medoxomil 1 (Benicar, Sankyo Pharma) is the latest angiotensin receptor antagonist $[2,3]$ approved by the FDA for the treatment of hypertension (Figure 1) [4]. The drug works by inhibiting the effects of angiotensin II, a potent vasoconstrictor and one of the key contributors to cardiovascular and renal disease $[5,6]$. During the process for the synthesis of (1), olmesartan medoxomil has been prepared by the following synthetic route $[4,7]$ described in Scheme 1.

\section{Experimental Section}

All reagents and solvents employed were of commercial grade and were used as such, unless otherwise specified. Reaction flasks were oven-dried at $200^{\circ} \mathrm{C}$, flame-dried, and flushed with dry nitrogen prior to use. All moisture and air-sensitive reactions were carried out under an atmosphere of dry nitrogen. TLC was performed on Kieselgel 60 F254 silica-coated aluminium plates (Merck) and visualized by UV light $(\lambda=$ $254 \mathrm{~nm}$ ) or by spraying with a solution of $\mathrm{KMnO}_{4}$. Organic extracts were dried over anhydrous $\mathrm{Na}_{2} \mathrm{SO}_{4}$. Flash chromatography was performed using Kieselgel 60 brand silica gel (230-400 mesh). The melting points were determined in an 


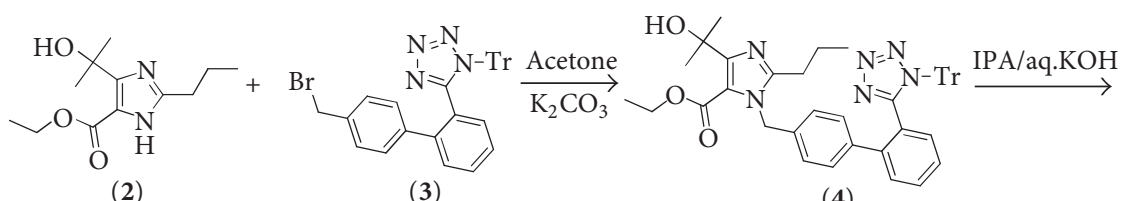

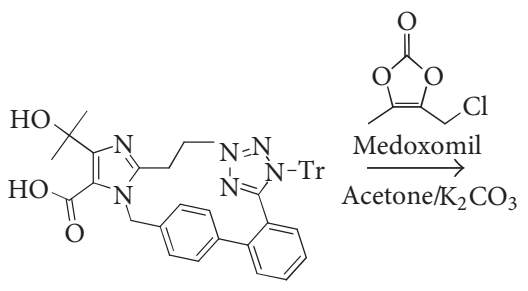

(5)

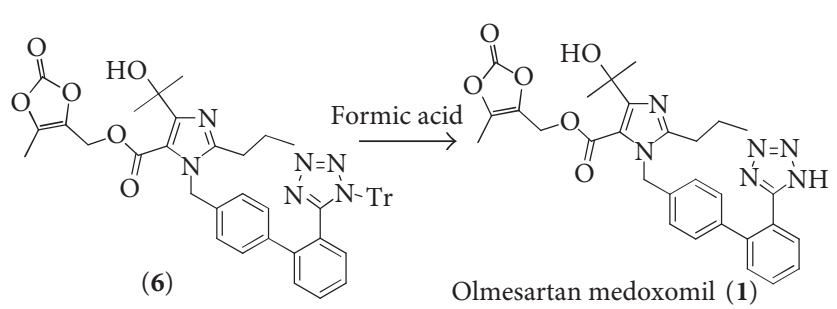

SCHEME 1: Synthesis of olmesartan medoxomil (1).

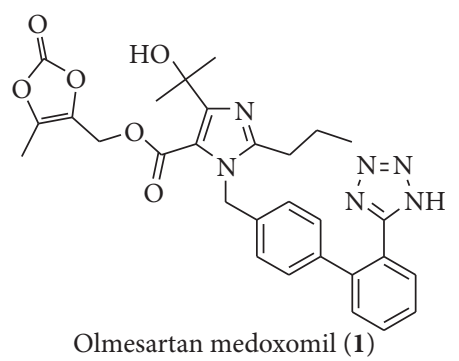

Figure 1

open capillary tube using a Büchi B-540 melting point instrument and were uncorrected. The IR spectra were obtained on a Nicolet 380 FT-IR instrument (neat for liquids and as $\mathrm{KBr}$ pellets for solids), HPLC (Agilent Technologies, 1200 series). NMR spectra were recorded with a Varian $300 \mathrm{MHz}$ Mercury Plus Spectrometer at $300 \mathrm{MHz}\left({ }^{1} \mathrm{H}\right)$. Chemical shifts were given in ppm relative to trimethylsilane (TMS). Mass spectra were recorded on Waters quattro premier XE triple quadrupole spectrometer using either electron spray ionisation (ESI) or atmospheric pressure chemical ionization (APCI) technique.

\subsection{Preparation of Isopropyl Impurity (12)}

2.1.1. Preparation of Ethyl 4-(2-hydroxypropan-2-yl)-2propyl-1-((2'-(1-trityl-1H-tetrazol-5-yl) biphenyl-4-yl) methyl)-1H-imidazole-5-carboxylate (4). To a solution of 4-(1-hydroxy-1-methylethyl)-2-propylimidazole-5-ethyl carboxylate (2) (4.0 g 0.016 mole) in acetone $(100 \mathrm{~mL})$ was added 4-((2-trityltetrazol-5-yl)-phenyl)-benzyl bromide (3) $(10.0 \mathrm{~g} 0.017$ mole), potassium carbonate $(5.7 \mathrm{~g}$, 0.043 mole), and tetrabutylammonium bromide (cat) at ambient temperature. The resulting mixture was heated at reflux for 22 hours. The reaction mixture was cooled to room temperature, filtered, and washed with acetone $(20 \mathrm{~mL})$. The combined filtrate and washings were concentrated under reduced pressure, and the residue partitioned between ethyl acetate $(2 \times 50 \mathrm{~mL})$ and water $(2 \times 40 \mathrm{~mL})$. The combined ethyl acetate layer was dried over anhydrous sodium sulfate and recovered at reduced pressure. To the residue $30 \mathrm{~mL}$ isopropyl alcohol was added, and the resulting solution was stirred at ambient temperature for 12 hours. The solids were filtered, washed with isopropyl alcohol $(15 \mathrm{~mL})$, and dried in air at $50-55^{\circ} \mathrm{C}$ for 16 hours to afford 4 as a white powder (11.0 g, 91\%).

2.1.2. Preparation of 1-(4-(2-Hydroxypropan-2-yl)-2-propyl1-((2'-(1-trityl-1H-tetrazol-5-yl) biphenyl-4-yl) methyl)-1Himidazol-5-yl)-3-methylbutan-1-one (13). To a solution of 4 ( $10.0 \mathrm{~g}, 0.0139 \mathrm{~mole})$ in isopropyl alcohol $(50 \mathrm{~mL})$ was slowly added a saturated solution of potassium hydroxide $(1.0 \mathrm{~g}$, 0.017 mole) at ambient temperature, and the reaction mixture was stirred at ambient temperature for 20-22 hrs. After completion of reaction distilled off IPA and added acetone $(70 \mathrm{~mL})$ followed by potassium carbonate $(3.0 \mathrm{~g}, 0.021 \mathrm{~mole})$ and stirred for $10 \mathrm{~min}$. Added 2-bromo propane $(1.8 \mathrm{~g}$, 0.0146 mole) at $40-45^{\circ} \mathrm{C}$, stirred for $4 \mathrm{hrs}$ at $45-50^{\circ} \mathrm{C}$. After completion of reaction, the mixture was filtered through hyflowbed and washed with acetone $(20 \mathrm{~mL})$, combined the acetone layer, and the solvents were concentrated under reduced pressure, the residue partitioned between ethyl acetate $(2 \times 75 \mathrm{~mL})$ and water $(2 \times 40 \mathrm{~mL})$. The combined ethyl acetate layer was dried over anhydrous sodium sulfate and recovered at reduced pressure to afford crude 13, which was purified by column chromatography on silica gel using $20 \%$ ethyl acetate in hexane to give $\mathbf{1 3}$ as viscous oil $(9.0 \mathrm{~g}$, $90 \%)$.

2.1.3. Preparation of 1-(1-((2'-(1H-Tetrazol-5-yl)biphenyl-4yl)methyl)-4-(2-hydroxy propan-2-yl)-2-propyl-1H-imidazol5-yl)-3-methylbutan-1-one (12). Formic acid (50 mL) was added to a solution of 13 ( $10.0 \mathrm{~g}, 0.0137$ mole) in methanolacetonitrile $(1: 1,150 \mathrm{~mL})$ and heated to $50^{\circ} \mathrm{C}$ for 4 hours. The solution was cooled to room temperature, and the solvents were removed under reduced pressure. The residue was taken in water $(100 \mathrm{~mL})$ and extracted with ethyl acetate $(2 \times$ $250 \mathrm{~mL}$ ). The combined organic extracts were washed with $15 \% \mathrm{NaHCO}_{3}$ solution $(50 \mathrm{~mL})$ and dried over anhydrous sodium sulfate. Evaporation of the solvents under reduced 
Known impurity-(7)

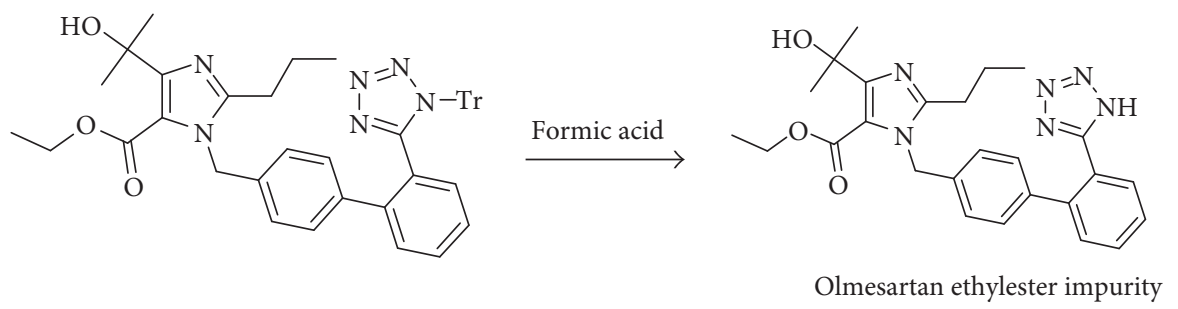

(4)

(7)

SCHEME 2: Synthesis of olmesartan medoxomil known impurity (7)

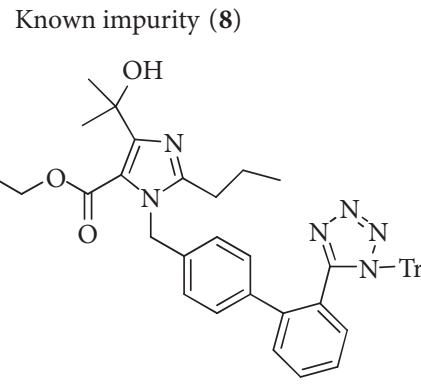

(4)

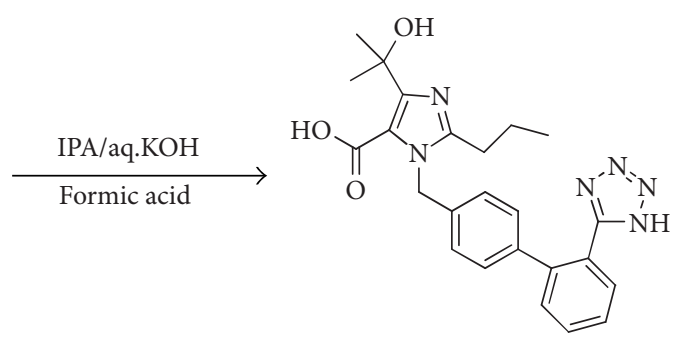

Olmesartan acid impurity

(8)

Scheme 3: Synthesis of olmesartan medoxomil known impurity (8)

pressure at $55^{\circ} \mathrm{C}$ afforded crude 12 which on purification by column chromatography on silica gel using $20 \%$ acetone in hexane afforded solid which on recrystallisation in $n$-heptane afforded pure $\mathbf{1 2}$ as a white solid $(5.0 \mathrm{~g}, 75 \%)$.

IR: $\left(\mathrm{KBr}, \mathrm{cm}^{-1}\right) 3409(\mathrm{NH}) ; 1664(\mathrm{C}=\mathrm{O}) ; 1219(\mathrm{Ar} \mathrm{C}-\mathrm{N})$; 1384, 1459 (Ar C=C); 1055.7, 957.7 (Ar C-H). ${ }^{1} \mathrm{H}$ NMR: (DMSO-d6) $0.96\left(\mathrm{t}, 3 \mathrm{H}, J=9.0\right.$ and $\left.7.2 \mathrm{~Hz}, \mathrm{CH}_{3}\right) ; 1.35(\mathrm{~s}, 6 \mathrm{H}$, $\left.2 \mathrm{CH}_{3}\right) ; 1.54\left(\mathrm{~s}, 6 \mathrm{H}, 2 \mathrm{CH}_{3}\right) ; 1.66\left(\mathrm{~m}, 2 \mathrm{H}, \mathrm{CH}_{2}\right) ; 2.55(\mathrm{t}, 2 \mathrm{H}, J=$ 7.5 and $\left.7.5 \mathrm{~Hz}, \mathrm{CH}_{2}\right) ; 4.31(\mathrm{~m}, 1 \mathrm{H}, \mathrm{OH}) ; 4.99$ (s, $\left.2 \mathrm{H}, \mathrm{CH}_{2}\right)$; 7.12-7.54 (m, 5H, Ar-H), ESI-MS: (m/z): 489, mp: $62-66^{\circ} \mathrm{C}$, Elemental analysis: calculated for $\mathrm{C}_{80} \mathrm{H}_{92} \mathrm{~N}_{18} \mathrm{O}_{9}$ : C, 66.37; $\mathrm{H}$, $6.60 ; \mathrm{N}, 17.20$; O, 9.82; found: $\mathrm{C}, 66.42 ; \mathrm{H}, 6.73 ; \mathrm{N}, 17.32 ; \mathrm{O}$, 9.97.

\subsection{Preparation of Dibiphenyl Impurity (17)}

2.2.1. Preparation of $\left(2^{\prime}-(1-\right.$ Trityl-1H-tetrazol-5-yl) biphenyl4-yl) methyl 4-(2-hydroxy propan-2-yl)-2-propyl-1-((2'-(1trityl-1H-tetrazol-5-yl) biphenyl-4-yl) methyl)-1H-imidazole5 -carboxylate1 (18). To a solution of 4 (10.0 g, 0.0139 mole) in isopropyl alcohol $(50 \mathrm{~mL})$ was slowly added a saturated solution of potassium hydroxide $(1.0 \mathrm{~g}, 0.017 \mathrm{~mole})$ at ambient temperature, and the reaction mixture was stirred at ambient temperature for 20-22 hrs. After completion of reaction distilled off IPA and added acetone $(70 \mathrm{~mL})$ followed by potassium carbonate $(3.0 \mathrm{~g}, 0.021 \mathrm{~mole})$ and stirred for 10 min. Added 5-( $4^{\prime}$-(bromomethyl) biphenyl-2-yl)-1-trityl$1 \mathrm{H}$-tetrazole $3(7.8 \mathrm{~g}, 0.0139 \mathrm{~mole})$ at $40-45^{\circ} \mathrm{C}$, stirred for
$4 \mathrm{hrs}$ at $45-50^{\circ} \mathrm{C}$. After completion of reaction, the mixture was filtered through hyflowbed and washed with acetone $(20 \mathrm{~mL})$, combined the acetone layer and the solvents were concentrated under reduced pressure, the residue partitioned between ethyl acetate $(2 \times 100 \mathrm{~mL})$ and water $(2 \times 50 \mathrm{~mL})$. The combined ethyl acetate layer was dried over anhydrous sodium sulfate and recovered at reduced pressure to afford crude 18, which was purified by column chromatography on silica gel using $10 \%$ methanol in ethyl acetate to give $\mathbf{1 8}$ as a brown colored powder (15.0 g, 92\%).

2.2.2. Preparation of $\left(2^{\prime}-(1 H-T e t r a z o l-5-y l)\right.$ biphenyl-4-yl) methyl 1-((2'-(1H-tetrazol-5-yl) biphenyl-4-yl) methyl)-4-(2hydroxypropan-2-yl)-2-propyl-1H-imidazole-5-carboxylate

(17). Formic acid $(50 \mathrm{~mL})$ was added to a solution of $18(10.0 \mathrm{~g}, 0.0085$ mole) in methanol-acetonitrile $(1: 1$, $200 \mathrm{~mL}$ ) and heated to $50^{\circ} \mathrm{C}$ for 7 hours. The solution was cooled to room temperature, and the solvents were removed under reduced pressure. The residue was taken in water $(150 \mathrm{~mL})$ and extracted with ethyl acetate $(2 \times 200 \mathrm{~mL})$. The combined organic extracts were washed with $15 \% \mathrm{NaHCO}_{3}$ solution $(60 \mathrm{~mL})$ and dried over anhydrous sodium sulfate. Evaporation of the solvents under reduced pressure at $55^{\circ} \mathrm{C}$ afforded crude 17 which on purification by column chromatography on silica gel using $10 \%$ methanol in ethyl acetate afforded solid which on recrystallisation in acetone afforded pure 17 as a white solid (4.0 g, 68\%). 


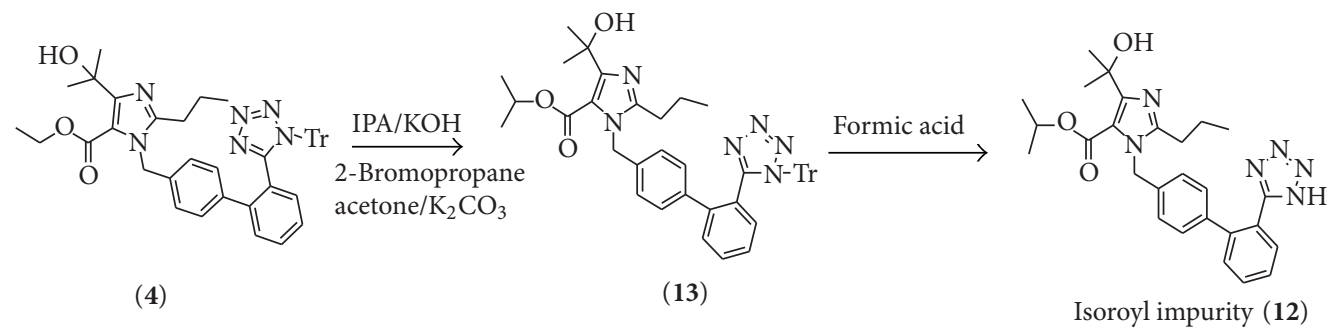

SCHEME 4: Synthesis of olmesartan medoxomil unknown impurity (12).

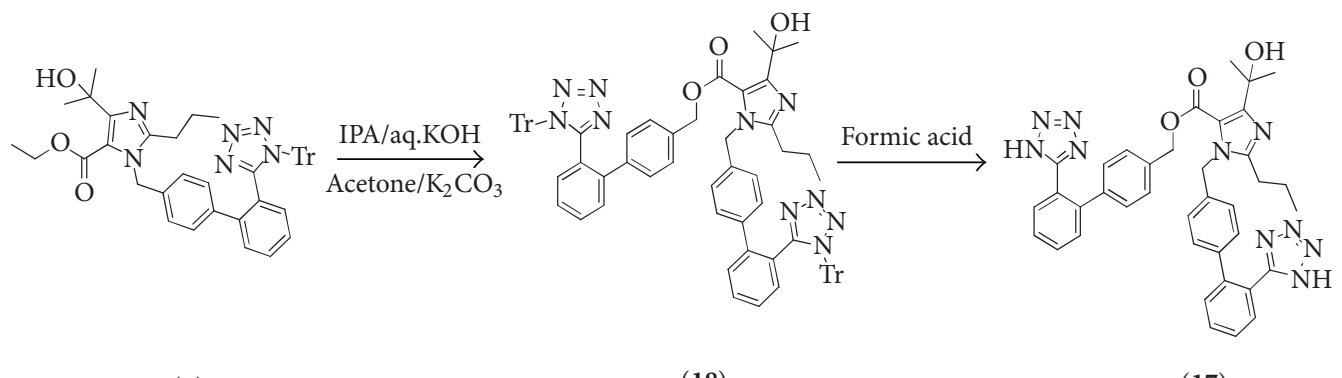

(4)

(18)

(17)

SCHEME 5: Synthesis of olmesartan medoxomil unknown impurity (17).

IR: $\left(\mathrm{KBr}, \quad \mathrm{cm}^{-1}\right) \quad 3404.9 \quad(\mathrm{~N}-\mathrm{H}) ; 1717.8 \quad(\mathrm{C}=\mathrm{O})$; 1099 (O-H); 1143.9 (Ar C-N); 1531-1610.2 (Ar C-C); 2874-2967.8 (C-H). ${ }^{1} \mathrm{H}$ NMR $\left(\mathrm{CDCl}_{3}\right) 0.96\left(\mathrm{t}, 3 \mathrm{H}, \mathrm{CH}_{3}\right)$; $1.54\left(\mathrm{~s}, 6 \mathrm{H}, 2 \mathrm{CH}_{3}\right): 1.66\left(\mathrm{~m}, 2 \mathrm{H}, \mathrm{CH}_{2}\right) ; 2.55\left(\mathrm{t}, 2 \mathrm{H}, \mathrm{CH}_{2}\right)$; $4.65\left(\mathrm{~s}, 2 \mathrm{H},-\mathrm{O}-\mathrm{CH}_{2}\right) ; 5.23\left(\mathrm{~s}, 2 \mathrm{H},-\mathrm{N}-\mathrm{CH}_{2}\right) ; 7.05-7.20(\mathrm{~m}$, $2 \mathrm{H}, \mathrm{Ar}-\mathrm{H}), 7.20-7.35$ (m, 6H, Ar-H); 7.42-7.50 (m, 4H, Ar-H); 7.60-7.77 (m, 4H, Ar-H). ESI-MS: (m/z): 679.5, mp: 78-82 ${ }^{\circ} \mathrm{C}$, Elemental analysis: calculated for $\mathrm{C}_{38} \mathrm{H}_{36} \mathrm{~N}_{10} \mathrm{O}_{3}$ : C, 67.04; H, 5.33; N, 20.58; O, 7.05; found: C, 67.17; H, 5.47; N, 20.62; O, 7.12.

\subsection{Preparation of Dimedoxomil Impurity}

2.3.1. Preparation of 1-((2'-(1H-Tetrazol-5-yl) biphenyl-4-yl) methyl)-4-(2-hydroxy propan-2-yl)-2-propyl-1H-imidazole-5carboxylic acid (8). To a solution of $4(10.0 \mathrm{~g}, 0.0139$ mole $)$ in isopropyl alcohol $(50 \mathrm{~mL})$ was slowly added a saturated solution of potassium hydroxide $(1.0 \mathrm{~g}, 0.017 \mathrm{~mole})$ at ambient temperature, and the reaction mixture was stirred at ambient temperature for 20-22 hrs. After completion of reaction distilled regular one and the crude mass dissolve in dichloromethane and methanol $(1: 1,100 \mathrm{~mL})$. Formic acid $(50 \mathrm{~mL})$ was added at $0-5^{\circ} \mathrm{C}$ and heated to $50^{\circ} \mathrm{C}$ for 7 hours. The solution was cooled to room temperature, and the solvents were removed under reduced pressure. The residue was taken in water $(150 \mathrm{~mL})$ and extracted with ethyl acetate $(2 \times 150 \mathrm{~mL})$. The combined organic extracts were washed with $15 \% \mathrm{NaHCO}_{3}$ solution $(80 \mathrm{~mL})$ and dried over anhydrous sodium sulfate. Evaporation of the solvents under reduced pressure at $55^{\circ} \mathrm{C}$ afforded crude 8 which on purification by column chromatography on silica gel using $10 \%$ methanol in dichloromethane afforded solid which on recrystallisation in acetone afforded pure $\mathbf{8}$ as a white solid (5.0 g, 83\%).

2.3.2. Preparation of (5-Methyl-2-oxo-1,3-dioxol-4-yl) methyl 4-(2-hydroxypropan-2-yl)-1-((2' -(1-((5-methyl-2-oxo-

1,3-dioxol-4-yl) methyl)-1H-tetrazol-5-yl) biphenyl-4-yl) methyl)-2-propyl-1H-imidazole-5-carboxylate (19). To a solution of $1-\left(\left(2^{\prime}-(1 \mathrm{H}-\right.\right.$ tetrazol-5-yl)biphenyl-4-yl)methyl)4-(2-hydroxypropan-2-yl)-2-propyl-1H-imidazole-5carboxylic acid 8 (10.0 g 0.022 mole) in acetone $(100 \mathrm{~mL})$ was added 4-(chloromethyl)-5-methyl-1,3-dioxol-2-one (medoxomil) (6.6 g 0.044 mole), potassium carbonate $(5.7 \mathrm{~g}$, 0.043 mole), and tetrabutylammonium bromide (cat) at ambient temperature. The resulting mixture was heated at reflux for 12 hours. The reaction was cooled to room temperature, filtered and washed with acetone $(40 \mathrm{~mL})$. The combined filtrate, and washings were concentrated under reduced pressure, and the residue partitioned between ethyl acetate $(2 \times 60 \mathrm{~mL})$ and water $(2 \times 20 \mathrm{~mL})$. The combined ethyl acetate layer was dried over anhydrous sodium sulfate and recovered at reduced pressure to afford crude 19, which was purified by column chromatography on silica gel using $10 \%$ methanol in dichloromethane afforded solid which on recrystallisation in acetone afforded pure $\mathbf{1 9}$ as an off-white colored powder (14.0 g, 93\%) (Scheme 6).

IR $\left(\mathrm{KBr}, \mathrm{cm}^{-1}\right) 3385(\mathrm{O}-\mathrm{H}) ; 2931(\mathrm{C}-\mathrm{H}) ; 2875(\mathrm{Ar}$ $\mathrm{C}-\mathrm{H}) ; 1816.4$ (Carbonate $\mathrm{C}=\mathrm{O}) ; 1741.9$ (Ester $\mathrm{C}=\mathrm{O}) ; 1531$ $(\mathrm{Ar} \mathrm{C}=\mathrm{C}) ; 1531(\mathrm{Ar} \mathrm{C}-\mathrm{N}) .{ }^{1} \mathrm{H}$ NMR $\left(\mathrm{CDCl}_{3}\right) 0.96(\mathrm{t}, 3 \mathrm{H}$, $\left.\mathrm{CH}_{3}\right) ; 1.54\left(\mathrm{~s}, 6 \mathrm{H}, 2 \mathrm{CH}_{3}\right) ; 1.66\left(\mathrm{~m}, 2 \mathrm{H}, \mathrm{CH}_{2}\right) ; 1.7-1.98(\mathrm{~s}, 6 \mathrm{H}$, $\left.2 \mathrm{CH}_{3}\right) ; 2.55\left(\mathrm{t}, 2 \mathrm{H}, \mathrm{CH}_{2}\right) ; 4.40\left(\mathrm{~s}, 2 \mathrm{H}, \mathrm{CH}_{2}\right) ; 4.92\left(\mathrm{~s}, 2 \mathrm{H}, \mathrm{CH}_{2}\right)$; 5.19 (s, 2H, $\left.\mathrm{CH}_{2}\right) ; 6.98$ (d, 2H, Ar-H); 7.28 (dd, 2H Ar-H); 7.45-7.80 (m, $4 \mathrm{H}, \mathrm{Ar}-\mathrm{H})$. Mass (m/e): 671.4 , mp: $126-130^{\circ} \mathrm{C}$, 


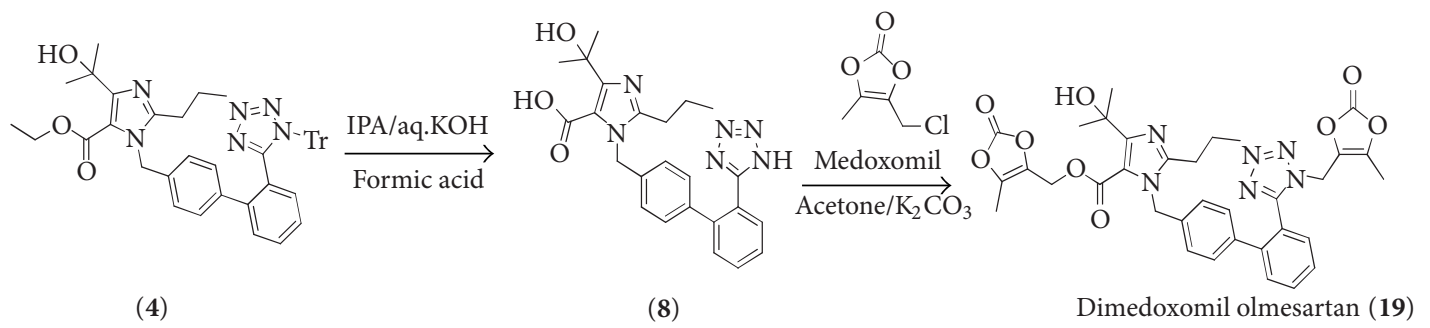

SCHeme 6: Synthesis of olmesartan medoxomil unknown impurity (19).

Elemental analysis: calculated for $\mathrm{C}_{34} \mathrm{H}_{34} \mathrm{~N}_{6} \mathrm{O}_{9}: \mathrm{C}, 60.89 ; \mathrm{H}$, $5.11 ; \mathrm{N}, 12.53$; O, 21.47; found: C, 60.91; H, 5.23; N, 12.62; O, 21.52 .

\section{Results and Discussion}

During the API process development of olmesartan medoxomil (1), various process-related impurities have been identified. Initially, two known impurities (7 and 8) were detected in HPLC of compound 1 (Figure 2), and besides, of these, three unknown impurities were also observed during the process development exercise for the preparation of olmesartan medoxomil following Scheme 1.

The two known impurities were prepared by Schemes 2 and 3 and characterized and conformed. The structural data of the known impurities were confirmed with literature reported values $[4,8-10]$.

A comprehensive study was undertaken to identify the unknown impurities by LC-MS followed by confirming through synthesis of respective unknown impurities, followed by characterization based on spectroscopic techniques such as ${ }^{1} \mathrm{H}$ NMR and IR mass spectroscopy.

Presence of these unknown impurities was detected by HPLC in synthesized olmesartan medoxomil (1) and studied the mechanistic aspect behind the formation of these and control the mentioned new impurities by improving reaction conditions and developed recrystallization techniques (to remove even if they formed). However, to the best of our knowledge, neither identification nor characterization nor synthesis of these three new process-related impurities was not reported so far.

The identified impurities present at nonpolar end of the chromatogram compared to required product. The RRT of unknown impurities 12, 17, and 19 are 1.09, 1.40, 1.63, respectively, each of the impurities contaminating the product with 0.2 to $0.5 \%$ (area by HPLC). Being researchers of organic chemistry, we intended to identify the possible structures by considering the molecular weights (by LCMS), followed by their synthesis and confirming through correlating these with the impurities forming in the reaction (by HPLC) (Figures 3, 4 and 5). The LC-MS details of unknown impurities were given in Table 1 .

The relevant chemical structures of the impurities were predicted by considering the mass details ( $\mathrm{m} / \mathrm{z}$ value) by
TABLE 1: Unknown impurity RRT.

\begin{tabular}{lcc}
\hline Entry number & RRT by HPLC & Mass (m/z) value by LC-MS \\
\hline 1 & 1.09 & 488.58 \\
2 & 1.40 & 680.76 \\
3 & 1.63 & 670.67 \\
\hline
\end{tabular}

LC-MS. While reviewing the mechanistic aspects of the possibilities of these impurities formation, the most probable structures were identified first and started synthesizing the same to confirm through structural elucidation followed by employing the chromatographic techniques (HPLC).

The unknown impurity $\mathbf{1 2}$ has lower $\mathrm{m} / \mathrm{z}$ value than that of olmesartan medoxomil and as per analysis of mass spectral data of LC-MS, presence of two extra methyl groups was suspected. Since mechanistic aspect of the 9, 10, 11 does not support much, usage of isopropanol may be causing trans esterfication and ending up with the product 12 having isopropyl ester. It was intended to synthesize the same thorough following the Scheme 4, and all the spectral data confirm the structure. Chromatographic studies (HPLC) with varying the concentration of impurity are also conducted and concluded that the same impurity existed in targeted entity Olmesartan medoxomil.

The unknown impurity $\mathbf{1 7}$ has higher $\mathrm{m} / \mathrm{z}$ value than that of olmesartan medoxomil, and as per analysis of mass spectral data of LC-MS, presence of extra biphenyl methyl containing tetrazole was suspected. Initially, suspected either of the first three structures $(14,15$, and 16) but if it is so, one should be able to recognize these prior to the hydrolysis stage only, that is, first step of the Scheme 1, as per LCMS analysis the relevant impurity was not detected, then the attention was shifted to the remaining predicted structure (17). The possibility could be remnant bromo compound 3 reactions with carboxylic acid 5 lead to the generation of the biphenyl methyl ester impurity. After progressing various transformation of Scheme 1, finally the olmesartan medoxomil is left with contamination of relevant impurity.

The proposed impurity was synthesized by following Scheme 5, and all the spectral data confirm the structure. Chromatographic studies (HPLC) with varying the concentration of impurity are also conducted and concluded that the same impurity existed in targeted entity olmesartan medoxomil. 


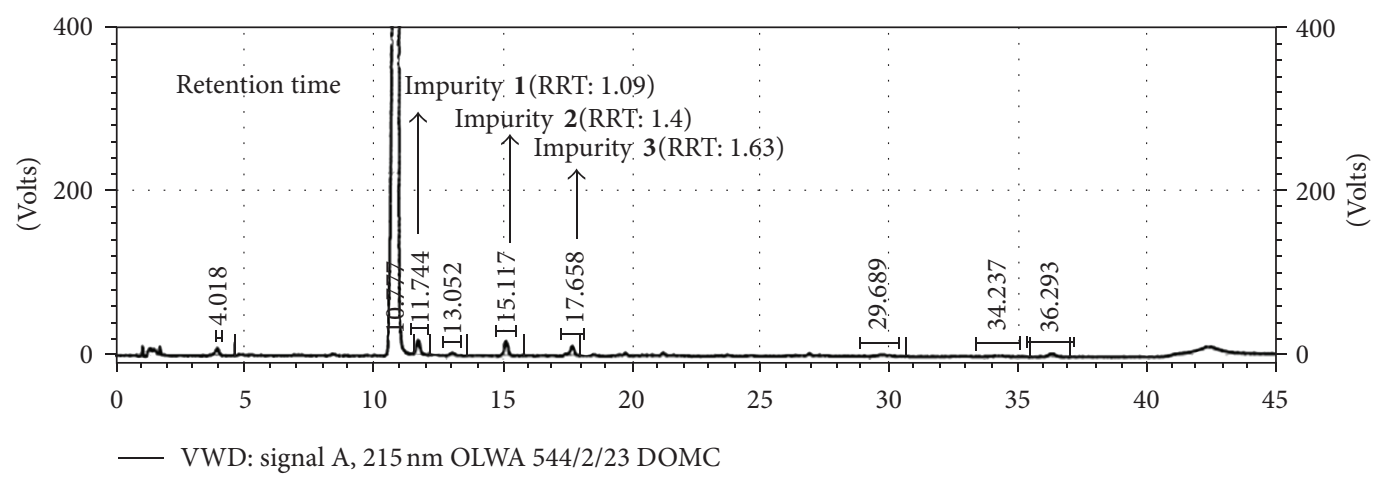

FIGURE 2: HPLC chromatogram of olmesartan medoxomil.

Unknown impurity (12) by LC-MS (M/Z: 488.58)

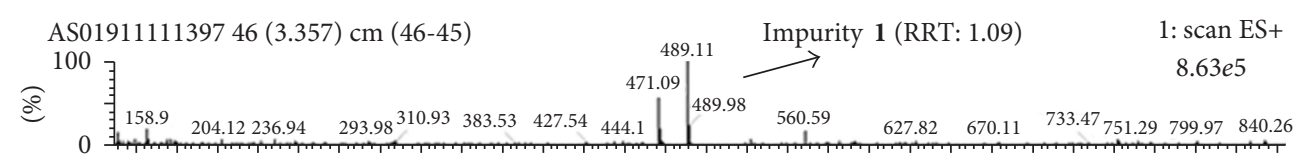

FIGURE 3: LC-MS chromatogram of unknown impurity (12).

Unknown impurity (17) by LC-MS (M/Z: 680.76)

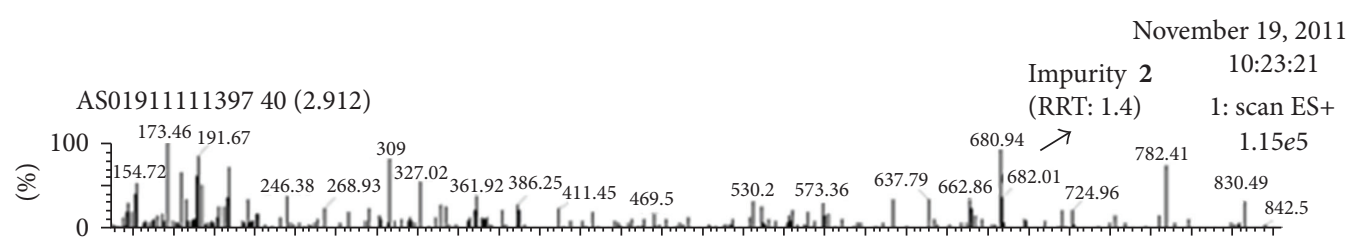

FIGURE 4: LC-MS chromatogram of unknown impurity (17).

Unknown impurity (19) by LC-MS (M/Z: 670.67)

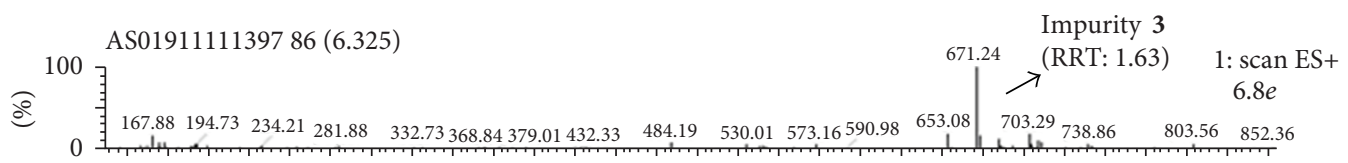

FIGURE 5: LC-MS chromatogram of unknown impurity (19).<smiles></smiles>

(9)

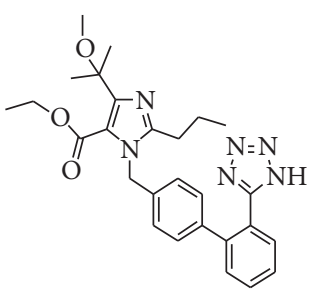

(10)

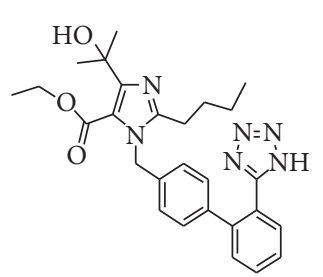

(11)

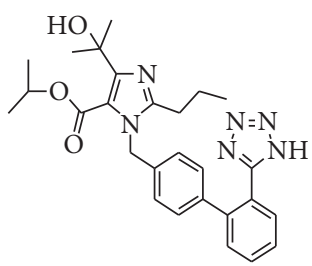

(12)

$\mathrm{C}_{27} \mathrm{H}_{32} \mathrm{~N}_{6} \mathrm{O}_{3}$ MWt: 488.58

$\mathrm{C}_{27} \mathrm{H}_{32} \mathrm{~N}_{6} \mathrm{O}_{3}$ MWt: 488.58

$\mathrm{C}_{27} \mathrm{H}_{32} \mathrm{~N}_{6} \mathrm{O}_{3}$ MWt: 488.58

$\mathrm{C}_{27} \mathrm{H}_{32} \mathrm{~N}_{6} \mathrm{O}_{3}$ MWt: 488.58

FIgURE 6: Proposed structures of "unknown impurity (12) (M/Z: 488.58)." 


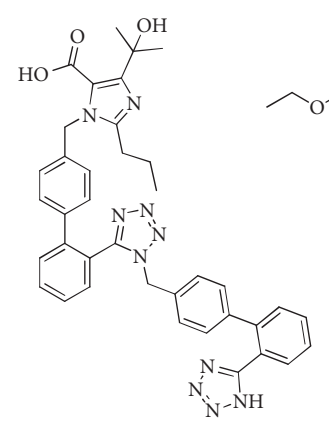

(14)

$\mathrm{C}_{38} \mathrm{H}_{36} \mathrm{~N}_{10} \mathrm{O}_{3}$ MWt: 680.76

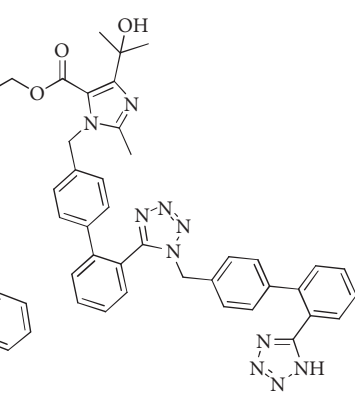

(15)

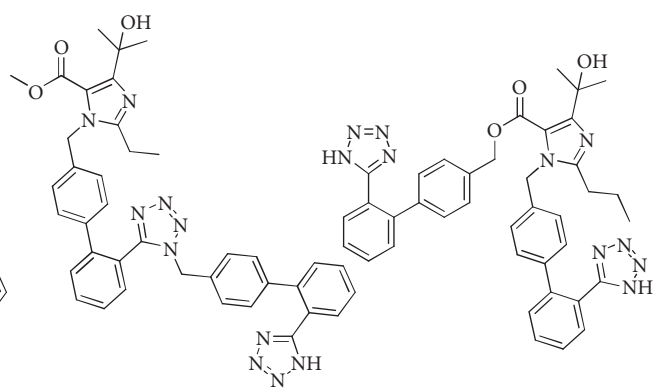

(16)
(17)

$\mathrm{C}_{38} \mathrm{H}_{36} \mathrm{~N}_{10} \mathrm{O}_{3}$ MWt: 680.76

$\mathrm{C}_{38} \mathrm{H}_{36} \mathrm{~N}_{10} \mathrm{O}_{3}$ MWt: 680.76

FIgURE 7: Proposed structures of “unknown impurity (17) (M/Z: 680.76).”

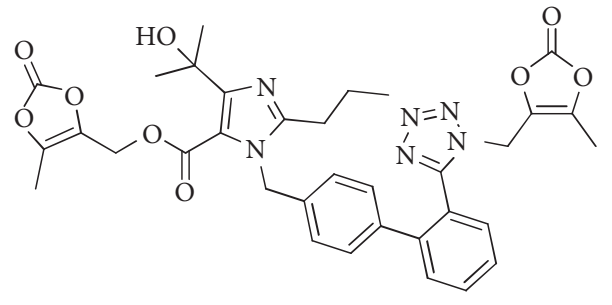

Dimedoxomil olmesartan (19)

FIGURE 8

Since the impurity is identified and mechanistic possibility of expected, the formation of the respective contaminant (impurity 17) was subsidized by assuring the absence of the bromo compound 3 in first reaction of Scheme 1.

\section{Unknown Impurity (19) (M/Z: 670.67)}

The unknown impurity 19 has higher $\mathrm{m} / \mathrm{z}$ value than that of olmesartan medoxomil and as per analysis of mass spectral data of LC-MS, presence of extra medoxomil moiety intacts with target chemical entity 1 . The possibility could be the reaction of known impurity 19 with medoxomil and leads to both $\mathrm{O}$ and $\mathrm{N}$ alkylation. It was prepared by employing the same strategy (mechanistic reason), and all the spectral data confirm the structure. Chromatographic studies (HPLC) with varying the concentration of impurity are also conducted and concluded that the same impurity existed in targeted entity olmesartan medoxomil.

\section{Proposed Structures of "Unknown Impurity (19) (M/Z: 670.76)"}

Since the impurity is identified and mechanistic possibility of expected, the formation of the respective contaminant (Impurity 19) was minimized by assuring the no excess presence of medoxomil in final reaction.
Chromatographic studies (HPLC) with varying the concentration and coinjection of impurity were also conducted and concluded that the same impurities were existed in targeted entity olmesartan medoxomil. The reason for formation is also discussed, and preventive studies were also carried out and process has been modified such that the formation of mentioned impurities is subsidized.

\section{Conclusion}

The possible process-related impurities of olmesartan medoxomil are identified by LC-MS data followed by confirmation by chemical synthesis and characterization using analytical tools such as HPLC, ${ }^{1}$ HNMR, IR, mass, and melting point.

\section{Acknowledgment}

The authors thank Inogent Laboratories Private Limited (a GVK BIO Company) for the financial support and encouragement.

\section{References}

[1] "International conference on harmonization (ICH) Guidelines," Q3A (R) Impurities in New Drug Substances, February 2002.

[2] M. Fukuda, T. Yamanaka, M. Mizuno et al., "Angiotensin II type 1 receptor blocker, olmesartan, restores nocturnal blood pressure decline by enhancing daytime natriuresis," Journal of Hypertension, vol. 26, no. 3, pp. 583-588, 2008.

[3] N. Kurikawa, M. Suga, S. Kuroda, K. Yamada, and H. Ishikawa, "An angiotensin II type 1 receptor antagonist, olmesartan medoxomil, improves experimental liver fibrosis by suppression of proliferation and collagen synthesis in activated hepatic stellate cells," British Journal of Pharmacology, vol. 139, no. 6, pp. 1085-1094, 2003.

[4] H. Yanagisawa, Y. Amemiya, T. Kanazaki et al., "Nonpeptide angiotensin II receptor antagonists: synthesis, biological activities, and structure-activity relationships of imidazole5-carboxylic acids bearing alkyl, alkenyl, and hydroxyalkyl 
substituents at the 4-position and their related compounds," Journal of Medicinal Chemistry, vol. 39, no. 1, pp. 323-338, 1996.

[5] S. F. Gardner, Franks, and A. M. Ann, "Olmesartan medoxomil: the seventh angiotensin receptor antagonist," Pharmacotherapy, vol. 37, no. 1, pp. 99-105, 2003.

[6] J. Teng, N. Fukuda, R. Suzuki, and H. Takagi, "Inhibitory effect of a novel angiotensin II type 1 receptor antagonist RNH-6270 on growth of vascular smooth muscle cells from spontaneously hypertensive rats: different anti-proliferative effect to angiotensin-converting enzyme inhibitor," Journal of Cardiovascular Pharmacology, vol. 39, no. 2, pp. 161-171, 2002.

[7] G. S. Ramanjaneyulu, B. Mohan, P. C. Ray et al., US2009/ 281327,[A1]English, 2009.

[8] S. Srimurugan, P. Suresh, B. Babu, S. G. Hiriyanna, and H. N. Pati, "Unusual detritylation of tritylated tetrazole in Sartan molecules," Chemical and Pharmaceutical Bulletin, vol. 56, no. 3, pp. 383-384, 2008.

[9] H. N. Pati, S. Lahiri, R. K. Sabbam et al., "A convenient and practical synthesis of olmesartan medoxomil methyl ether," Journal of Heterocyclic Chemistry, vol. 45, no. 3, pp. 917-920, 2008.

[10] K. S. Babu, A. R. Tagore, G. S. Reddy, P. P. Reddy, R. V. Anand, and G. Venkateswarlu, "Synthesis of related substances of olmesartan medoxomil, antihypertensive drug," Arkivoc, vol. 2010, no. 2, pp. 292-302, 2010. 

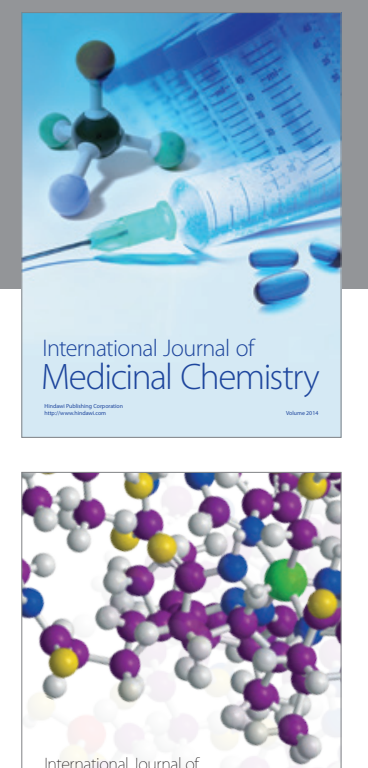

\section{Carbohydrate} Chemistry

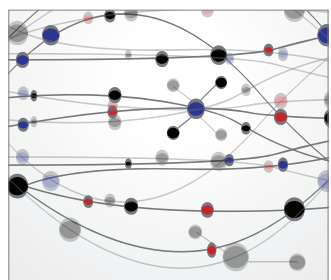

The Scientific World Journal
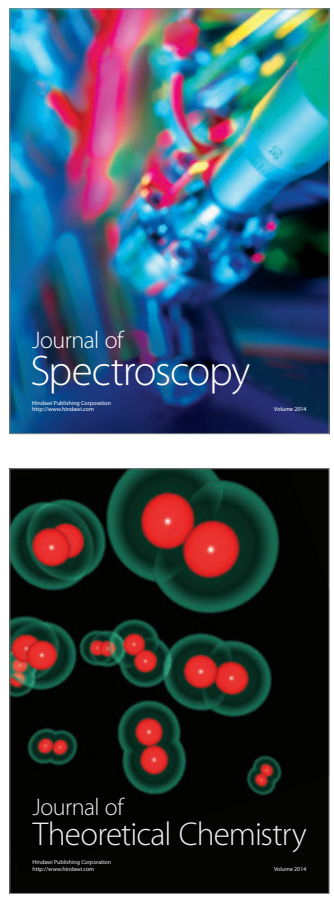
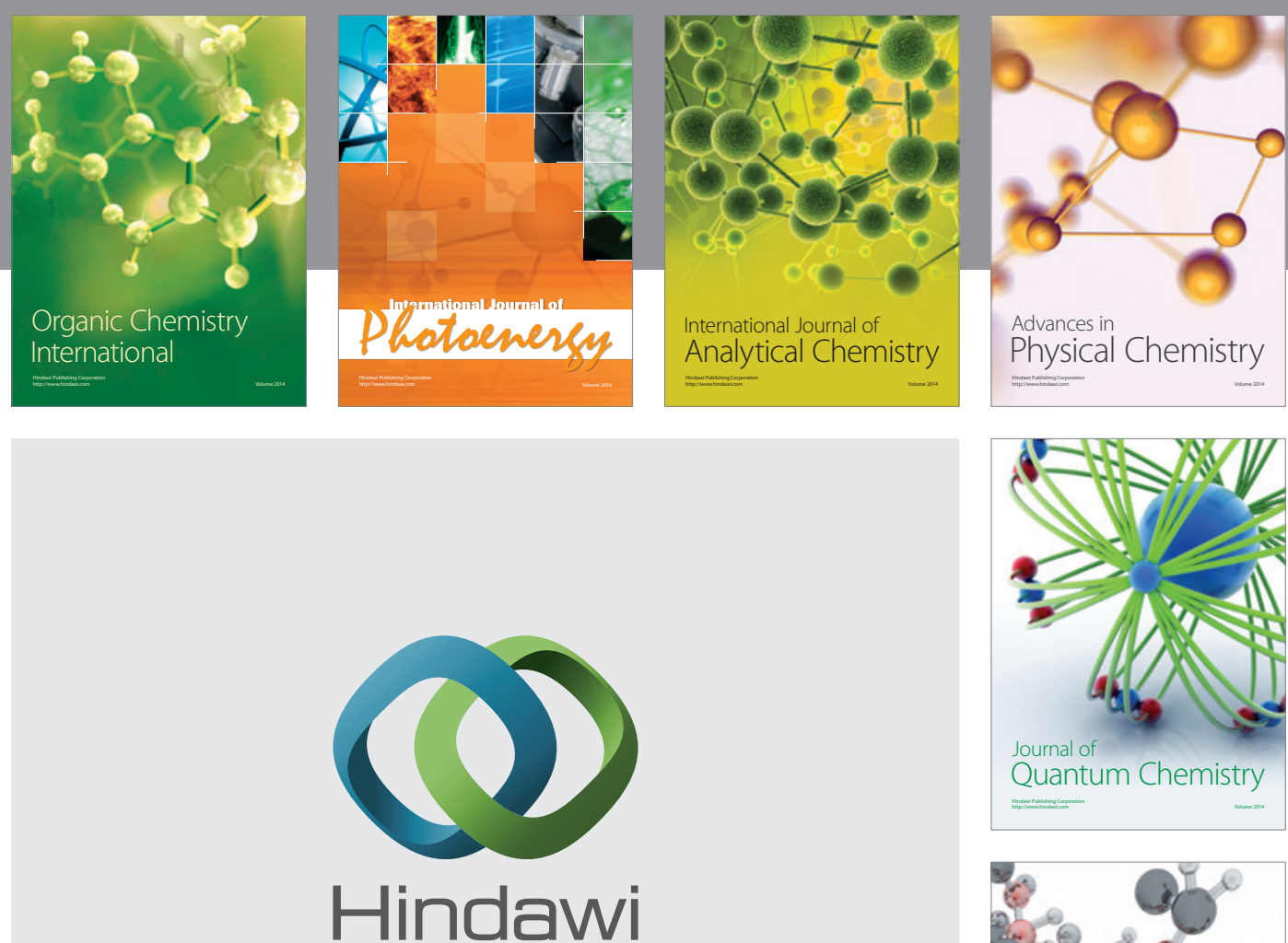

Submit your manuscripts at

http://www.hindawi.com

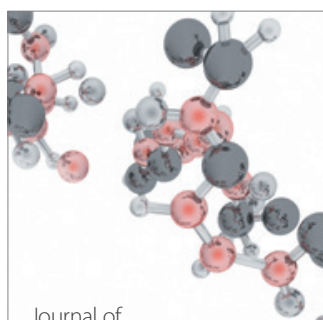

Analytical Methods

in Chemistry

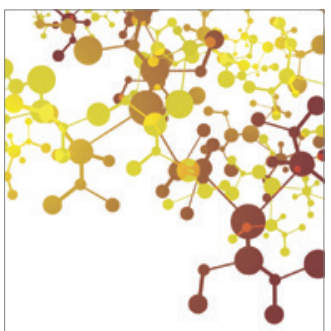

Journal of

Applied Chemistry

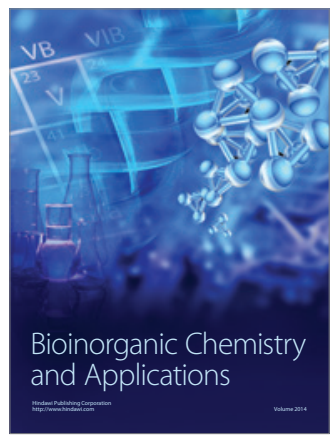

Inorganic Chemistry
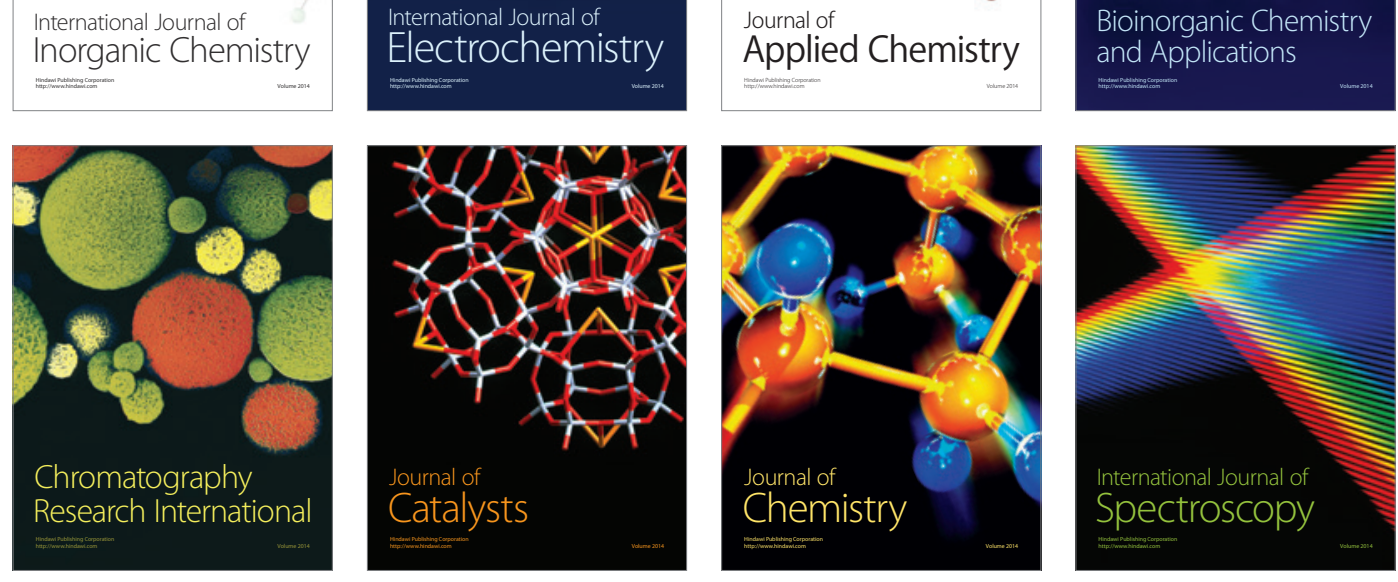